\title{
Ripening of 'Kumagai' guavas and anthracnose control as affected by methyl jasmonate
}

\author{
Barbara Marçon Pereira da Silva ${ }^{1}$, Raquel Mantovani Binotii ${ }^{1}$, Patrícia $\mathrm{Cia}^{2}$, Sílvia Regina de Toledo \\ Valentini ${ }^{1}$, Ilana Urbano Bron ${ }^{1 \star}$ \\ 1. Instituto Agronômico - Centro de Ecofisiologia e Biofísica - Campinas (SP), Brazil. \\ 2. Instituto Agronômico - Centro de Engenharia e Automação - Jundiaí (SP), Brazil.
}

\begin{abstract}
Methyl jasmonate (MJ) is an endogenous regulator that can influence fruit ripening and the defense system against pathogens. This work verified the influence of this regulator on postharvest physiology, control of anthracnose and physicalchemical attributes of 'Kumagai' guava (Psidium guajava L.). Guavas harvested at mature-green and ripe stages were treated with 0, 1 and $10 \mu \mathrm{mol} \cdot \mathrm{L}^{-1} \mathrm{MJ}$ as gas in hermetic containers (200 L) with air circulation for $24 \mathrm{~h}$. Fruit were inoculated with Colletotrichum gloeosporioides spore suspension $\left(10^{5}\right.$ spores $\left.\cdot \mathrm{mL}^{-1}\right) 24$ and $48 \mathrm{~h}$ after treatment. During ripening, at $25{ }^{\circ} \mathrm{C}$ and $80-90 \%$ of relative humidity, respiration, ethylene production, anthracnose incidence, severity and quality of guavas were assayed. Data were subjected
\end{abstract}

to analysis of variance and means, compared by Tukey's test ( $p \leq 0.05$ and 0.10 ). The application of 1 and $10 \mu \mathrm{mol} \cdot \mathrm{L}^{-1} \mathrm{MJ}$ had little influence on ripening of 'Kumagai' guava with a slight increase in respiration, ethylene production and yellowing of fruit harvested at ripe stage. Treatments with 1 and $10 \mu \mathrm{mol} \cdot \mathrm{L}^{-1} \mathrm{MJ}$ did not reduce the severity and incidence of $C$. gloeosporioides when applied in fruit harvested at ripe and mature-green stages and inoculated 24 or $48 \mathrm{~h}$ after $\mathrm{MJ}$ treatment. In conclusion, the MJ treatment, at 1 and $10 \mu \mathrm{mol} \cdot \mathrm{L}^{-1}$ concentrations, had little influence on ripening and did not control anthracnose in 'Kumagai' guavas.

Key words: Colletotrichum gloeosporioides, Psidium guajava L., growth regulator.

*Corresponding author: ilana@iac.sp.gov.br 


\section{INTRODUCTION}

Guava is very appreciated for its nutritional and organoleptic qualities, favoring the growth of its market share. However, its intense metabolic activity during ripening shortens the shelf life and, consequently, the commercialization of this fruit. Another factor that can hinder marketing is infection by microorganisms, including Colletotrichum spp., the anthracnose causal agent (Pandey et al. 1997).

Several methods are used to minimize the ripening effects on fruit and reduce the incidence of postharvest pathogens, among them is the use of plant growth regulators (Terry and Joyce 2004).

Methyl jasmonate (MJ) is a regulator that can influence many aspects of plant growth and development (Creelman and Mullet 1997; Cortes 2000). Moreover, it is involved in the protection against biotic and abiotic stresses, playing a central role in inducing plant defense mechanisms (Gundlach et al. 1992).

Treatment with MJ effectively reduced anthracnose in loquats (Cao et al. 2008) and tomatoes (Tzortzakis 2007), inhibited rot caused by Botrytis cinerea in strawberries (Zhang et al. 2006), reduced the incidence of Penicillium expansum and Monilinia fructicola in peaches (Yao and Tian 2005b) and Penicillium digitatum in grapefruit (Droby et al. 1999). MJ is expected to interfere with ripening physiology, since it is involved in resistance to different types of stress. MJ applied to unripe strawberries increased respiration and ethylene production and induced anthocyanin biosynthesis and chlorophyll degradation (Pérez et al. 1997; Mukkun and Singh 2009). In contrast, Soto et al. (2012) reported that MJ delayed ripening of peaches, which was indicated by the inhibitory effect of the regulator on ethylene biosynthesis.

An interesting fact is that fruit response to $\mathrm{MJ}$ treatment is apparently associated with the regulator concentration (Buta and Moline 1998), fruit development stage at the time of MJ application, and the differences between species/cultivars (Fan et al. 1997; Pérez et al. 1997).

In this context, this study investigated the effect of $2 \mathrm{MJ}$ concentrations on postharvest physiology, physicalchemical characteristics and anthracnose control in 'Kumagai' guavas harvested in two ripening stages.

\section{MATERIAL AND METHODS}

The experiments were conducted at the Postharvest Technology Laboratory of the Agronomic Institute (IAC) in Campinas (SP), Brazil. 'Kumagai' guavas were harvested from a commercial orchard, in 2 ripening stages, ripe and mature-green, visually assessed by skin color (Figure 1).

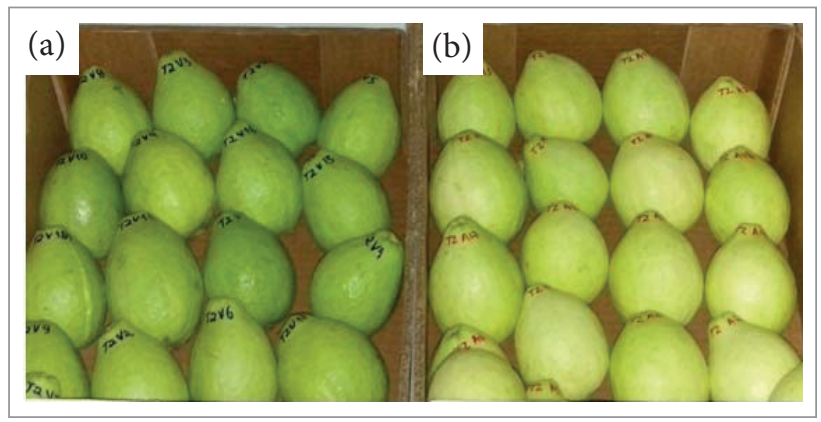

Figure 1. Kumagai guavas harvested mature-green (a) and ripe (b).

In the first experiment, guavas were placed into hermetic containers $(200 \mathrm{~L})$ with forced air circulation at $25{ }^{\circ} \mathrm{C}$. The specified volumes, corresponding to 1 and $10 \mu \mathrm{mol} \cdot \mathrm{L}^{-1}$ of $\mathrm{MJ}$, were placed on filter paper into plates, which were subsequently placed inside the containers just before the containers were closed. The fruit were exposed to MJ for $24 \mathrm{~h}$. Control samples were handled similarly with filter paper soaked in distilled water. Two batches of fruit were inoculated with Colletotrichum gloeosporioides, 24 and $48 \mathrm{~h}$ after the MJ treatments had started. The inoculation was performed by subcuticular wound using a $100 \mu \mathrm{L}$ chromatographic syringe (Hamilton $\left.{ }^{\circledR}\right)$ to introduce $10 \mu \mathrm{L}$ of the suspension containing $10^{5}$ spores $\cdot \mathrm{mL}^{-1}$ in the equatorial region of each fruit. The spore suspension was prepared by adding $15 \mathrm{~mL}$ of distilled water in a petri dish containing the pathogen colony, previously incubated for 8 days on potato dextrose agar (PDA) at $25{ }^{\circ} \mathrm{C}$. The concentration of the spore suspension was determined in a Neubauer hemacytometer. The inoculated area was previously marked with a pen to confirm that the symptoms were due to inoculation rather than a field infection. After inoculation, the fruit were stored at $25^{\circ} \mathrm{C}$, with $80-90 \%$ of relative humidity, and evaluated daily for the incidence (percentage of fruit presenting symptoms) and severity (lesion diameter) 
of anthracnose. Disease development was assessed in 5 replicates with 4 fruit as experimental unit. The data (decay incidence and severity) were used to calculate the area under the disease progress curve (AUDPC), according to the following equation (De Capdeville et al. 2002):

$$
\mathrm{AUDPC}=\sum\left[\left(y_{i}+y_{i+1}\right) / 2 \times\left(t_{i+1}-t_{i}\right)\right]
$$

where: $y_{i}$ is the disease incidence in the $i^{\text {th }}$ observation; $t_{i}$ is the time, in days, in the $i^{\text {th }}$ observation.

The physical-chemical attributes of the fruit were analyzed every 2 days. Firmness was evaluated with manual penetrometer (Efegi, FT-327 model), with 8-mm cylindrical tip, on 2 equatorial opposite sides of the fruit, and expressed as N. Soluble solids (SS) were determined with the ATTO-2WAJ refractometer and expressed as ${ }^{\circ}$ Brix. Titratable acidity (TA) was determined by titration according to Carvalho et al. (1990) and expressed as citric acid percentage (\%). Fruit skin color was evaluated with a Color Reader CR-10, Konica Minolta $\left(\mathrm{L}, \mathrm{C}\right.$, and ${ }^{\circ} \mathrm{H}$ ), with 2 readings per fruit. Ascorbic acid content was determined by titration with DCFI and results expressed as mg of ascorbic acid per $100 \mathrm{~g}$ pulp (Carvalho et al. 1990). The physical-chemical attributes were evaluated in 2 fruit as experimental unit and 4 replicates.

For the assessment of respiration and ethylene production, 10 fruit were weighed ( $166 \mathrm{~g}$ in average), placed into glass jars of $250 \mathrm{~mL}$, stored at $25{ }^{\circ} \mathrm{C}$ and $85-90 \%$ of relative humidity for 7 days. Every day, the jars were closed for $1 \mathrm{~h}$ and, after that period, gaseous samples of $1 \mathrm{~mL}$ were collected from each jar using a chromatographic syringe for dosing ethylene and $\mathrm{CO}_{2}$. Samples were analyzed with a gas chromatographer, Varian 450 - GC (BRUKER), equipped with flame ionization detector (FID) and thermal conductivity detector (TCD) to determine $\mathrm{CO}_{2}$ and ethylene production. The temperatures of the column, injector, FID and TCD were 80; 120; 250; and $200{ }^{\circ} \mathrm{C}$, respectively, while the gas flows were $20 ; 30 ; 300$; and $20 \mathrm{~mL} \cdot \mathrm{min}^{-1}$ for helium, used as a carrier gas, hydrogen, synthetic air, and TCD reference gas, respectively. The results were calculated by the difference between the initial (closed jars) and final (after $1 \mathrm{~h}$ ) gas concentrations by comparison with
$\mathrm{CO}_{2}$ and $\mathrm{C}_{2} \mathrm{H}_{4}$ standards. The results were expressed as $\mathrm{mL} \mathrm{CO} \mathrm{CO}_{2} \cdot \mathrm{kg}^{-1} \cdot \mathrm{h}^{-1}$ and $\mu \mathrm{L} \mathrm{C}_{2} \mathrm{H}_{4} \cdot \mathrm{kg}^{-1} \cdot \mathrm{h}^{-1}$.

Experiments were performed according to a completely randomized design in a triple factorial (2 ripening stages $\times 3 \mathrm{MJ}$ concentrations $\times$ days of storage). Analysis of variance (ANOVA) of physical-chemical, respiration and ethylene data was performed for this experiment using ASSISTAT software. Differences at $\mathrm{p} \leq 0.05$ were considered significant according to Tukey's test. Data for anthracnose incidence and severity in guavas were compared by Tukey's test at $10 \%$, using Sisvar software.

Based on the first experiment, a second assay was conducted to confirm the results of anthracnose control. For this purpose, only ripe 'Kumagai' guavas were treated with $1 \mu \mathrm{mol} \cdot \mathrm{L}^{-1} \mathrm{MJ}$, inoculated $48 \mathrm{~h}$ after $\mathrm{MJ}$ treatment had started. Fruit were evaluated daily for incidence and severity of anthracnose. The methods and evaluations were the same described in the first experiment.

The experimental design was completely randomized in a triple factorial arrangement (ripening stage $\times$ MJ concentration $x$ days of storage). Data for anthracnose incidence and severity in guavas were compared by Tukey's test at 10\%, using Sisvar software.

\section{RESULTS AND DISCUSSION}

Mature-green fruit treated or not with MJ showed constant respiration rate until the fifth storage day. After this period, there was a significant increase $(\mathrm{p} \leq 0.05)$ in respiratory activity of both treated and untreated guavas, corresponding to 53 and $57 \mathrm{~mL} \mathrm{CO} \cdot \mathrm{kg}^{-1} \cdot \mathrm{h}^{-1}$, respectively, on the seventh day. There was no difference between treatments during the storage period $(p>0.05)$ (Figure $2 a)$. The respiration increased $(p \leq 0.05)$ in ripe fruit treated with MJ, regardless the concentration. On the seventh day of storage, the fruit untreated and treated with 1 and $10 \mu \mathrm{mol} \cdot \mathrm{L}^{-1} \mathrm{MJ}$ had a respiratory activity of $39 ; 62$, and $54 \mathrm{~mL} \mathrm{CO}{ }_{2} \cdot \mathrm{kg}^{-1} \cdot \mathrm{h}^{-1}$, respectively (Figure $2 \mathrm{~b}$ ).

Ethylene production of both treated and untreated mature-green guavas increased ( $p \leq 0.05)$ during storage, with no difference between treatments, in most of the period. Only at the end of storage, on the sixth 
day, the fruit treated with $10 \mu \mathrm{mol} \cdot \mathrm{L}^{-1} \mathrm{MJ}$ produced more ethylene compared to untreated fruit $(\mathrm{p} \leq 0.05)$ (Figure 2c). Ethylene production of untreated ripe guavas increased and reached maximum values of 23.3 $\mu \mathrm{L} \mathrm{C}_{2} \mathrm{H}_{4} \cdot \mathrm{kg}^{-1} \cdot \mathrm{h}^{-1}$, after 5 days of storage. On the other hand, ethylene production of treated guavas

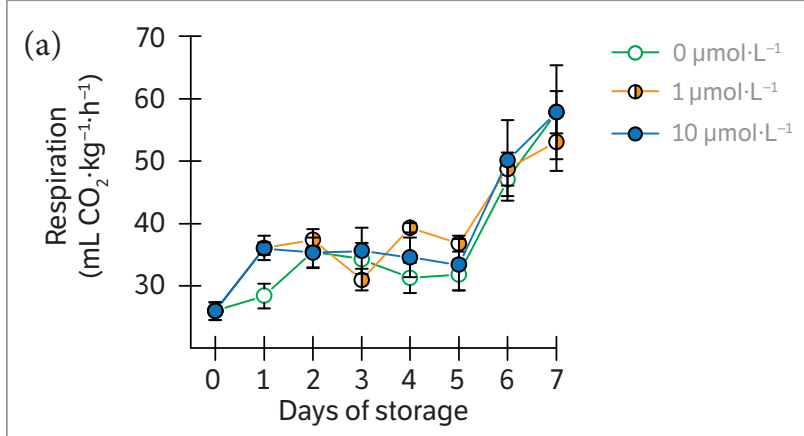

(b)

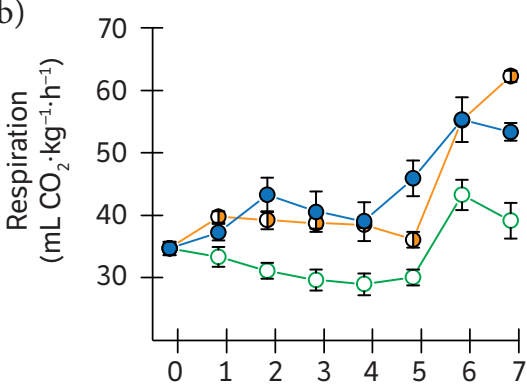

(c)

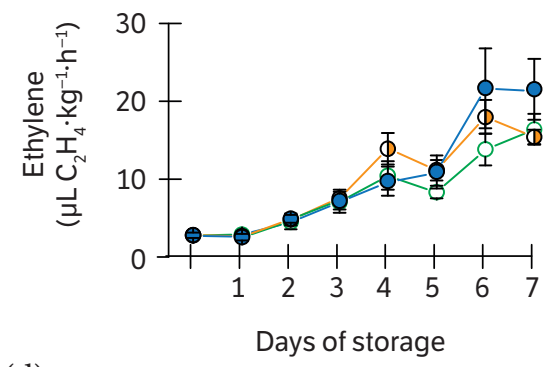

(d)

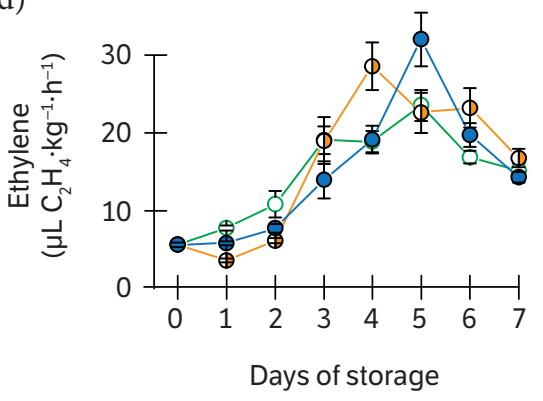

Figure 2. Respiration ( $\left.\mathrm{mL} \mathrm{CO}_{2} \cdot \mathrm{kg}^{-1} \cdot \mathrm{h}^{-1}\right)$ and ethylene production $\left(\mu \mathrm{L} \mathrm{C}_{2} \mathrm{H}_{4} \cdot \mathrm{kg}^{-1} \cdot \mathrm{h}^{-1}\right)$ of 'Kumagai' guavas harvested mature-green $(a, c)$ and ripe $(b, d)$ treated with $\mathrm{MJ}$ and stored at $25^{\circ} \mathrm{C}$ and $85-90 \%$ of relative humidity for 7 days. Vertical bars indicate means standard error $(n=10)$. peaked on the fourth and fifth days with values of 28 and $31 \mu \mathrm{L} \mathrm{C}_{2} \mathrm{H}_{4} \cdot \mathrm{kg}^{-1} \cdot \mathrm{h}^{-1}$ for 1 and $10 \mu \mathrm{mol} \cdot \mathrm{L}^{-1} \mathrm{MJ}$, respectively $(\mathrm{p} \leq 0.05)$ (Figure 2d).

Regardless of the treatments, pulp firmness decreased during storage for both ripe and mature-green fruit. Only on the first day, pulp firmness was higher for maturegreen fruit treated with $10 \mu \mathrm{mol} \cdot \mathrm{L}^{-1} \mathrm{MJ}$ compared to other treatments, followed by untreated fruit and fruit treated with $1 \mu \mathrm{mol} \cdot \mathrm{L}^{-1} \mathrm{MJ}(\mathrm{p} \leq 0.05)$ (Figure 3a). For the ripe guavas, there was no significant difference in pulp firmness among $\mathrm{MJ}$ treatments $(\mathrm{p}>0.05)$ (Figure 3b).

In mature-green fruit treated with $\mathrm{MJ}$, regardless of the concentration, the change of skin color, from green to yellow, was faster than the untreated fruit $(p \leq 0.05)$ (Figure 3c). This effect of MJ treatment was evident from the fourth to the sixth day of storage $(p \leq 0.05)$. Regardless of concentration, the skin color of ripe fruit was also influenced by MJ. At the beginning of storage, mainly in the first 3 days, and also on the sixth day, the treated fruit had lower hue values $(\mathrm{p} \leq 0.05)$ (Figure 3d).

The acidity of mature-green fruit treated with $1 \mu \mathrm{mol} \cdot \mathrm{L}^{-1} \mathrm{MJ}$ decreased during the ripening process compared to other treatments $(\mathrm{p} \leq 0.05)$ (Figure 3i). The acidity of the untreated fruit did not change during storage $(\mathrm{p}>0.05)$. For the ripe fruit, there were almost no changes in the acidity, regardless of the treatment $(p>0.05)$ (Figure $3 j)$.

Only on the third day, the SS content of mature-green fruit treated with $1 \mu \mathrm{mol} \cdot \mathrm{L}^{-1} \mathrm{MJ}$ was significantly different from the untreated fruit; however, there were no other significant differences during the storage $(\mathrm{p} \leq 0.05)$ (Figure 3g). In addition, significant difference was observed between the SS of untreated ripe fruit and fruit treated with $1 \mu \mathrm{mol} \cdot \mathrm{L}^{-1} \mathrm{MJ}$ on the first and third days $(\mathrm{p} \leq 0.05)$. There was no difference between the SS of the fruit treated with 1 and $10 \mu \mathrm{mol} \cdot \mathrm{L}^{-1} \mathrm{MJ}$ $(\mathrm{p}>0.05)$ (Figure $3 \mathrm{~h})$.

The ascorbic acid content of mature-green fruit increased from the first day of storage. Although not significant, this increase was enhanced by the MJ treatments. On the seventh day of storage, while the untreated fruit had $84.3 \mathrm{mg}$ ascorbic acid per $100 \mathrm{~g}$ of pulp, those treated with 1 and $10 \mu \mathrm{mol} \cdot \mathrm{L}^{-1} \mathrm{MJ}$ had 91.7 and $95.3 \mathrm{mg}$ ascorbic acid per $100 \mathrm{~g}$ of pulp, respectively (Figure $3 \mathrm{e}$ ). The ascorbic acid 
content was significantly different only on the fifth day between untreated fruit and those treated with $10 \mu \mathrm{mol} \cdot \mathrm{L}^{-1}$ $\mathrm{MJ}$ ( $\mathrm{p} \leq 0.05)$. Ripe fruit also had few significant differences according to MJ concentration ( $\mathrm{p} \leq 0.05)$ (Figure 3f).
Anthracnose symptoms were visible from the second storage day after inoculation. In the first experiment, it was observed that the MJ treatment did not affect the incidence and severity of anthracnose in both

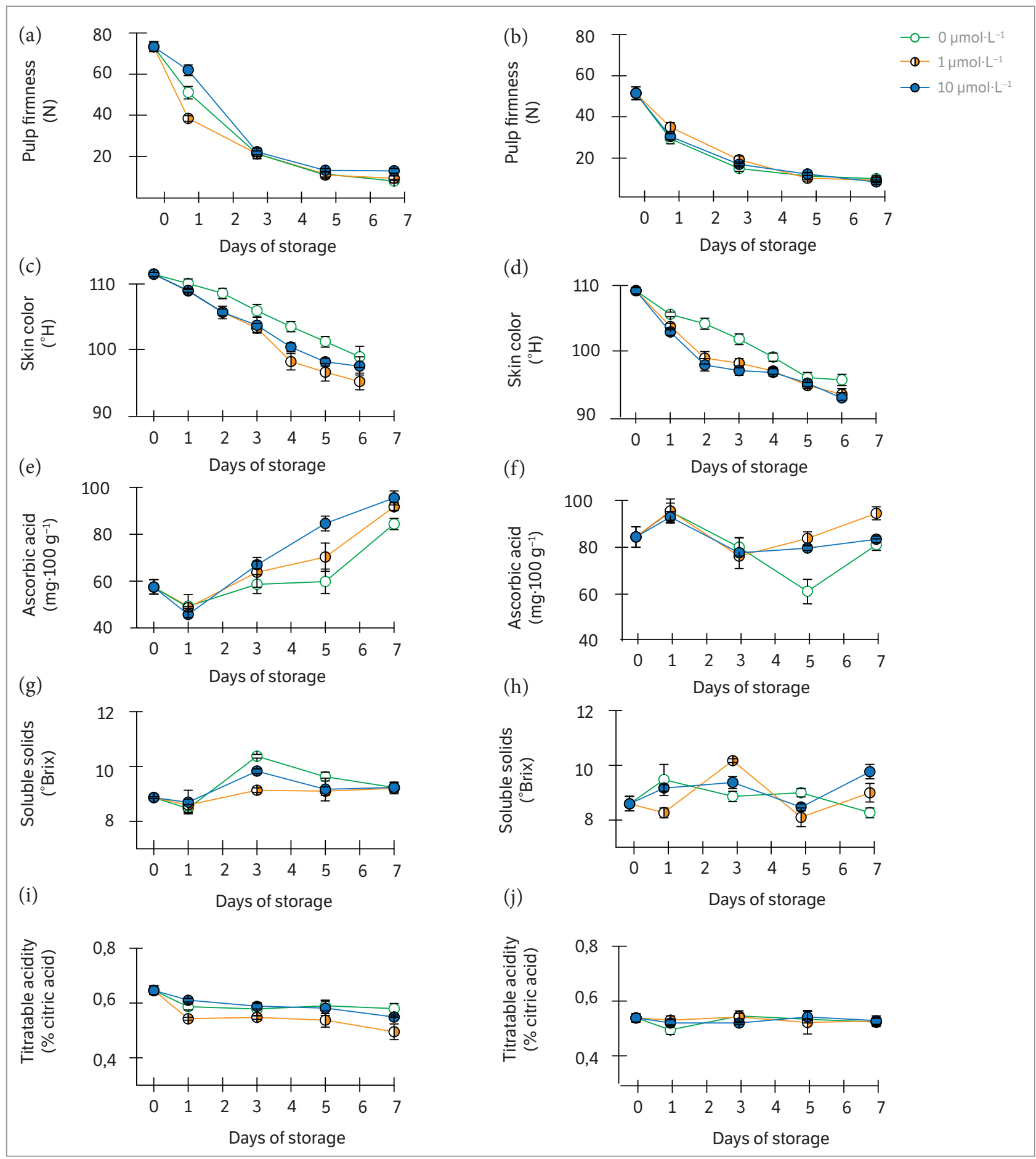

Figure 3. Pulp firmness ( $\mathrm{N})$, skin color $\left({ }^{\circ} \mathrm{H}\right)$, soluble solids ( ${ }^{\circ}$ Brix), titratable acidity (\% citric acid), and ascorbic acid $\left(\mathrm{mg}^{\circ} 100 \mathrm{~g}^{-1}\right)$ of 'Kumagai' guavas harvested mature-green ( $a, c, e, g, i)$ and ripe (b, d, f, h, j) treated with $\mathrm{MJ}$ and stored at $25{ }^{\circ} \mathrm{C}$ and $85-90 \%$ of relative humidity for 7 days. Vertical bars indicate means standard error $(n=4)$. 
treated and untreated fruit, when inoculation was performed $24 \mathrm{~h}$ after MJ was applied $(\mathrm{p}>0.10)$ (Figure $4 \mathrm{a}, \mathrm{c})$. However, $\mathrm{MJ}$ treatment influence was observed when inoculation was performed after $48 \mathrm{~h}$ from the beginning of the treatment. According to AUDPC, i.e. the whole storage period, it was observed that the incidence and severity of anthracnose were significantly influenced only by the $1 \mu \mathrm{mol} \cdot \mathrm{L}^{-1} \mathrm{MJ}$ treatment in ripe 'Kumagai' guavas inoculated after $48 \mathrm{~h}(\mathrm{p} \leq 0.10)$ (Figure 4b, d).

In the second assay, the previous result was not confirmed; the $1 \mu \mathrm{mol} \cdot \mathrm{L}^{-1} \mathrm{MJ}$ concentration used to treat 'Kumagai' ripe guavas, inoculated after $48 \mathrm{~h}$, did not reduce the incidence and severity of anthracnose $(\mathrm{p}>0.10)$. The result for the AUDPC was 510 and 550 for disease incidence and 15.6 and 16.7 for disease severity, in treated and untreated fruit, respectively.

The use of $\mathrm{MJ}$ increased respiration and ethylene production in 'Kumagai' guavas, mainly in the ripe ones (Figure $2 \mathrm{~b}, \mathrm{~d}$ ), accelerating the ripening process. The effects of this slight increase can be observed by the rapid loss of green color of the skin (Figure $3 \mathrm{~d}$ ) and the increase of ascorbic acid in the treated fruit (Figure 3f). For guavas, skin color, from green to yellow, is a good indicator of ripeness stage. Changes in skin color are related to ethylene production, which has increased in MJ treated fruit (Figure 2d). This process affects the expression of enzymes, such as chlorophyllases and the carotenoid biosynthesis (Wills et al. 1999).

According to many studies, the exogenous application of $\mathrm{MJ}$ promotes the ripening of climacteric fruit by stimulating ethylene production, as observed in peaches (Ziosi et al. 2008) and mangoes (Lalel et al. 2003). In apples and tomatoes, the increase of endogenous jasmonate induces the production of ethylene from system I to II, and, moreover, low jasmonate concentrations ( 0.001 to $\left.1 \mu \mathrm{mol} \cdot \mathrm{L}^{-1}\right)$ can induce physiological changes in these fruit (Fan et al. 1997). The application of exogenous $\mathrm{MJ}$ increases ACC oxidase activity preceding the ACC synthase activity (Yu et al. 2009), suggesting that the ACC oxidase activity is the key-step for controlling ethylene production in response to $\mathrm{MJ}$ application (Larrigaudiere and Vendrell 1993). The effect of MJ is directly related not only to the enzymes associated with ethylene synthesis, but also to the increase of lipoxygenase (LOX) activity, as observed in different plants (Cheong and Yang 2007; González-Aguilar et al. 2003). The superoxide radicals formed by LOX activate the ACO and, consequently, the ethylene biosynthesis.

The use of exogenous MJ in lychees increased the activity of superoxide dismutase (SOD), catalase (CAT) and glutathione peroxidase (GPX), probably reducing

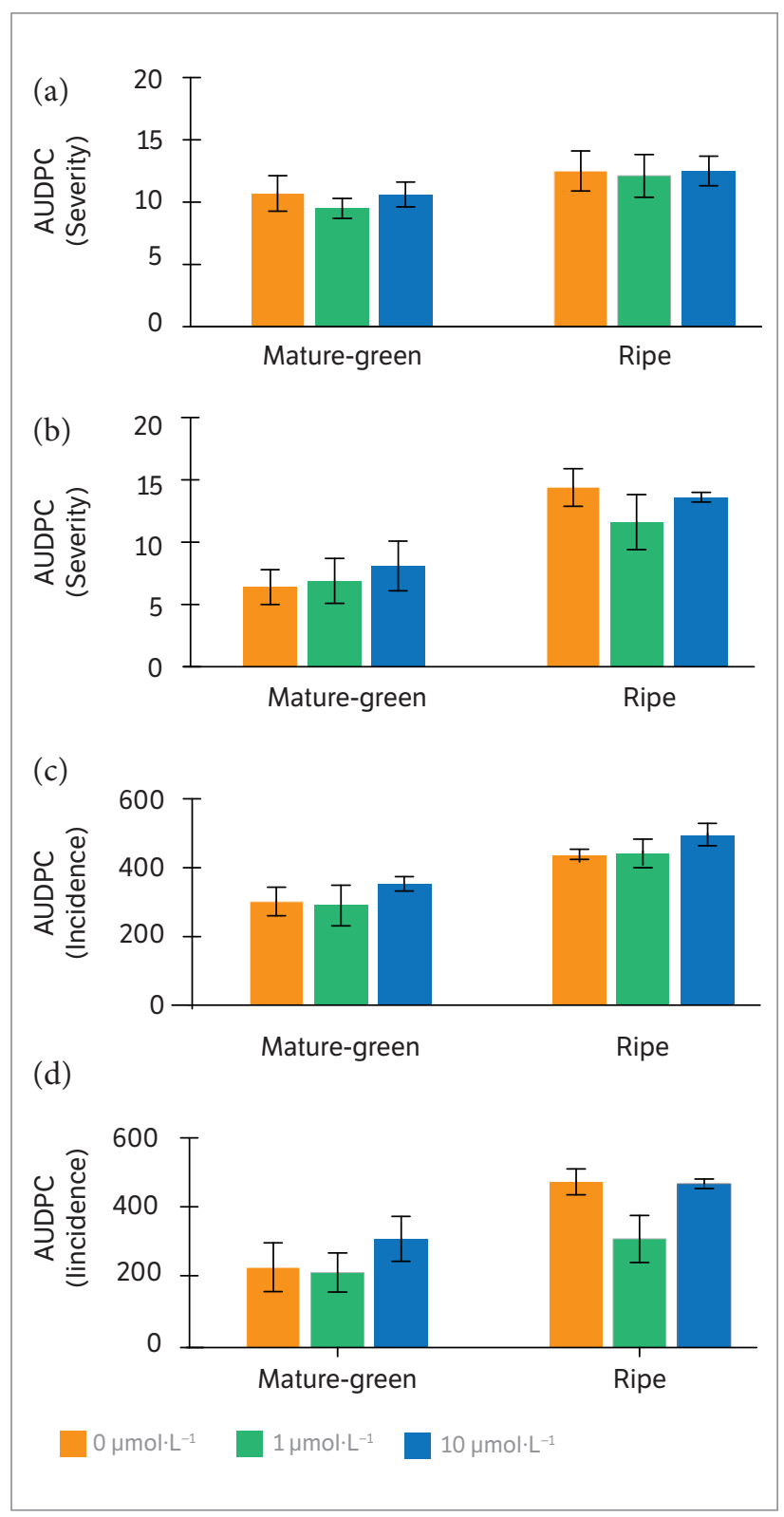

Figure 4. Area under the disease progress curve (AUDPC) for severity $(\mathrm{cm})$ and incidence $(\%)$ of anthracnose in 'Kumagai' guavas harvested ripe and mature-green, inoculated $24 \mathrm{~h}(\mathrm{a}, \mathrm{c})$ and $48 \mathrm{~h}(\mathrm{~b}, \mathrm{~d})$ after the treatment with 0,1 , and $10 \mu \mathrm{mol} \cdot \mathrm{L}^{-1}$ of $\mathrm{MJ}$ and stored at $25{ }^{\circ} \mathrm{C}$ and $85-90 \%$ of relative humidity for 8 days. Vertical bars indicate means standard error $(n=5)$. 
physiological and biochemical changes, increasing the antioxidant capacity and prolonging the postharvest storage at low temperature (Venkatachalam and Meenune 2015).

The effects of exogenous $\mathrm{MJ}$ on fruit ripening are not clear yet and are dependent on the species, cultivars, and physiological stage of the fruit (Fan et al. 1997; Khan and Singh 2007; Ziosi et al. 2008; Kucuker and Ozturk 2014).

According to Saniewski et al. (1987), MJ treatments may accelerate or retard fruit ripening, by the positive or negative effect on ethylene production, and are also related to the ripening stage. Saniewski (1997) demonstrated that the treatment promoted ethylene production in apples in pre-climacteric stage, but reduced ethylene production when applied in the post-climacteric stage. In unripe strawberries, jasmonate treatments increased respiration, while, in ripe or fully ripe fruit, $\mathrm{CO}_{2}$ production was reduced (Pérez et al. 1997).

The effects of MJ on the physical-chemical attributes were also contradictory. When applied in mangoes stored at $20^{\circ} \mathrm{C}, \mathrm{MJ}$ enhanced color changes without affecting firmness and weight loss (González-Aguilar et al. 2001). Studies have shown that MJ treatment decreased firmness in strawberries (Pérez et al. 1997), but did not affect the firmness of 'Tommy Atkins' mangoes (GonzálezAguilar et al. 2000). According to Ziosi et al. (2008), MJ is responsible for delaying polygalacturonase transcription during ripening, and this result depends on the cultivar and $\mathrm{MJ}$ concentration.

Nilprapruck et al. (2008) reported that the titratable acidity, SS, and total and reducing sugar contents of pineapples treated with $10^{-3} ; 10^{-4}$; and $10^{-5} \mathrm{M}$ of $\mathrm{MJ}$ and stored at $10{ }^{\circ} \mathrm{C}$ were not significantly different compared to the control fruit. However, contrary effects have been reported; raspberries treated with MJ showed higher SS, total sugar, fructose, glucose, sucrose, malic and citric acid contents than untreated fruit (Wang and Zheng 2005). In plums, Kucuker and Ozturk (2014) reported that the MJ-treated fruit had higher pulp firmness.

The incidence and severity of anthracnose were significantly reduced when the fruit were inoculated $48 \mathrm{~h}$ after MJ treatment (Figure $4 \mathrm{~b}, \mathrm{~d}$ ). Yao and Tian (2005a) stated that resistance induction and systemic protection are a gradual process. Thus, the period of
$48 \mathrm{~h}$ was long enough to induce resistance against the pathogen. The time interval to establish the induced state is an inherent characteristic of the induced resistance process (Hammerschmidt and Kuc 1995). El Ghaouth et al. (2003) investigated the role of Candida saitoana in inducing resistance against $B$. cinerea in freshly harvested apples stored at $4{ }^{\circ} \mathrm{C}$ and concluded that the treatment with the antagonistic microorganism $48 \mathrm{~h}$ after the pathogen inoculation reduced lesion size by $50 \%$ compared to treatment carried out $24 \mathrm{~h}$ after inoculation. Thus, the ideal resistance inducer must combine a short response interval with an extended protection (Hammerschmidt and Kuc 1995).

The response to $\mathrm{MJ}$ application was more evident in ripe fruit (Figure 4). The effect of the ripening stage was also confirmed by the physiological and postharvest quality results.

The results for incidence and severity of anthracnose also indicated differences according to MJ concentrations and the period of pathogen inoculation. Ripe fruit treated with $1 \mu \mathrm{mol} \cdot \mathrm{L}^{-1} \mathrm{MJ}$ and inoculated $48 \mathrm{~h}$ after the treatment had lower incidence and severity of anthracnose (Figure 4b,d). Jin et al. (2009) also reported that $1 \mu \mathrm{mol} \cdot \mathrm{L}^{-1} \mathrm{MJ}$ was the most effective concentration for the control of Penicillium expansum, B. cinerea, and Rhizopus stolonifer in peaches. In contrast, Cao et al. (2008) evaluated the effect of $\mathrm{MJ}$ in reducing the incidence of C. acutatum in loquat stored at $20^{\circ} \mathrm{C}$ and observed that the $10 \mu \mathrm{mol} \cdot \mathrm{L}^{-1}$ concentration was the most effective.

In addition to the characteristics of the species, the effect of jasmonates as a plant growth regulator is related to its structure and the concentrations applied, among other factors. The use of high MJ concentrations leads to a stimulation of ripening and, thus, senescence (Buta and Moline 1998; Pérez et al. 1993), which may counteract the positive effect on induced resistance (GonzálezAguilar et al. 2003) and predispose the fruit to infection. Anderson (1989) and Mason and Mullet (1990) reported that high $\mathrm{MJ}$ concentrations $\left(50 \mu \mathrm{mol} \cdot \mathrm{L}^{-1}\right)$ induced senescence in cell cultures, and lower concentrations ( 1 to $10 \mu \mathrm{mol} \cdot \mathrm{L}^{-1}$ ) modulate mRNA transcription and proteins expression without inducing senescence. Zapata et al. (2014) investigated pre-harvest MJ application in plums and found that the concentration of $2 \mathrm{mM}$ accelerated fruit ripening while $0.5 \mathrm{mM}$ delayed it. 
In the second experiment, the $1 \mu \mathrm{mol} \cdot \mathrm{L}^{-1} \mathrm{MJ}$ concentration had no effect on the control of anthracnose. Therefore, as the defense against biotic and abiotic stresses in plants consists in a complex network of responses, the effect of postharvest treatment varies considerably. Further studies in order to investigate the relationships between fruit ripening stages, $\mathrm{MJ}$ concentrations, and control mechanisms of this compound are still necessary.

\section{CONCLUSION}

The application of 1 and $10 \mu \mathrm{mol} \cdot \mathrm{L}^{-1} \mathrm{MJ}$ had little influence on ripening. The respiration rate, ethylene production and yellowing of the skin increased in ripe 'Kumagai' guavas. Furthermore, the concentrations of 1 and $10 \mu \mathrm{mol} \cdot \mathrm{L}^{-1} \mathrm{MJ}$ did not control anthracnose in the fruit.

\section{REFERENCES}

Anderson, J. M. (1989). Membrane-derived fatty acids as precursors to second messengers. In W. F. Boss and D. J. Morre (Eds.), Second messengers in plant growth and development (p. 181-212). New York: Alan R. Liss.

Buta, J. G. and Moline, H. E. (1998). Methyl jasmonate extends shelf life and reduces microbial contamination of fresh-cut celery and peppers. Journal of Agricultural and Food Chemistry, 46, 1253-1256. http://dx.doi.org/10.1021/jf9707492.

Cao, S., Zheng, Y., Yang, Z., Tang, S., Jin, P., Wang, K. and Wang, X. (2008). Effect of methyl jasmonate on the inhibition of Colletotrichum acutatum infection in loquat fruit and the possible mechanisms. Postharvest Biology and Technology, 49, 301-307. http://dx.doi.org/10.1016/j.postharvbio.2007.12.007.

Carvalho, C. R. L., Mantovani, D. M. B., Carvalho, P. R. N. and Moraes, R. M. M. (1990). Análises químicas de alimentos. Campinas: ITAL.

Cheong, J. J. and Yang, D. C. (2007). Signaling pathways for the biosynthesis and action of jasmonates. Journal of Plant Biology, 50, 122-131. http://dx.doi.org/10.1007/BF03030620.

Cortes, H. P. (2000). Introdução aos hormônios vegetais. Brasília: Embrapa.

Creelman, R. A. and Mullet, J. E. (1997). Biosynthesis and action of jasmonates in plants. Annual Review of Plant Physiology and Plant Molecular Biology, 48, 355-381.

De Capdeville, G., Wilson, C. L., Beer, S. V. and Aist, J. R. (2002). Alternative disease control agents induce resistance to blue mold in harvested 'Red Delicious' apple fruit. Phytopathology, 92 , 900-908. http://dx.doi.org/10.1094/PHYTO.2002.92.8.900.

Droby, S., Porat, R., Cohen, L., Weiss, B., Shapio, B., PhilosophHadas, S. and Meir, S. (1999). Suppressing green mold decay in grapefruit with postharvest jasmonate application. Journal of the American Society for Horticultural Science, 124, 184-188.

El Ghaouth, A., Wilson, C. L. and Wisniewski, M. (2003). Control of postharvest decay of apple fruit with Candida saitoana and induction of defense responses. Phytopathology, 93, 344-348. http://dx.doi.org/10.1094/PHYTO.2003.93.3.344.

Fan, X., Mattheis, J. P., Fellman, J. K. and Patterson, M. E. (1997). Effect of methyl jasmonate on ethylene and volatile production by Summerred apples depends on fruit developmental stage. Journal of Agricultural and Food Chemistry, 45, 208-211. http://dx.doi.org/10.1021/jf9603846.

González-Aguilar, G. A., Fortiz, J., Cruz, R., Baez, R. and Wang, C. Y. (2000). Methyl jasmonate reduces chilling injury and maintains postharvest quality of mango fruit. Journal of Agricultural and Food Chemistry, 48, 515-519. http://dx.doi. org/10.1021/jf9902806.

González-Aguilar, G. A., Wang, C. Y. and Buta, J. G. (2001). Methyl jasmonate reduces chilling injury symptoms and enhances colour development of 'Kent' mangoes. Journal of the Science of Food and Agriculture, 81, 1244-1249. http://dx.doi.org/10.1002/jsfa.933.

González-Aguilar, G. A., Wang, C. Y. and Buta, J. G. (2003). Methyl jasmonate and modified atmosphere packaging (MAP) reduce decay and maintain postharvest quality of papaya 'Sunrise'. Postharvest Biology and Technology, 28, 361-370. http://dx.doi.org/10.1016/S0925-5214(02)00200-4.

Gundlach, H., Miller, M. J., Kutchan, T. M. and Zenk, M. H. (1992). Jasmonic acid is a signal transducer in elicitor-induced plant cell cultures. Proceedings of the National Academy of Sciences of the United States of America, 89, 2389-2393. 
Hammerschmidt, R. and Kuc, J. (1995). Induced resistance to disease in plants. Dordrecht: Kluwer Academic Publishers.

Jin, P., Zheng, Y., Tang, S., Rui, H. and Wang, C. Y. (2009). Enhancing disease resistance in peach fruit with methyl jasmonate. Journal of the Science of Food and Agriculture, 89, 802-808. http://dx.doi.org/10.1002/jsfa.3516.

Khan, A. S. and Singh, Z. A. S. (2007). Methyl jasmonate promotes fruit ripening and improves fruit quality in Japanese plum. Journal of Horticultural Science \& Biotechnology, 82, 695-706. http://dx.doi.org/10.1080/14620316.2007.11512293.

Kucuker, E. and Ozturk, B. (2014). Effects of pre-harvest methyl jasmonate treatment on post-harvest fruit quality of Japanese plums. African Journal of Traditional, Complementary and Alternative Medicines, 11, 105-117. http://dx.doi.org/10.4314/ ajtcam.v11i6.11.

Lalel, H. J. D., Singh, Z. and Tan, S. C. (2003). The role of methyl jasmonate in mango ripening and biosynthesis of aroma volatile compounds. Journal of Horticultural Science \& Biotechnology, 78, 470-484. http://dx.doi.org/10.1080/146 20316.2003.11511652.

Larrigaudiere, C. and Vendrell, M. (1993). Cold-induced climacteric rise of ethylene metabolism in Granny Smith apples. In J. C. Pech and C. Balague (Eds.), Cellular and molecular aspects of the plant hormone ethylene (p. 136-141). Boston: Kluwer Academic Publishers.

Mason, H. S. and Mullet, J. E. (1990). Expression of two soybean vegetative storage protein genes during development and in response to water deficit, wounding, and jasmonic acid. Plant Cell, 2, 569-579. http://dx.doi.org/10.1105/tpc.2.6.569.

Mukkun, L. and Singh, Z. (2009). Methyl jasmonate plays a role in fruit ripening of 'Pajaro' strawberry through stimulation of ethylene biosynthesis. Scientia Horticulturae, 123, 5-10. http:// dx.doi.org/10.1016/j.scienta.2009.07.006.

Nilprapruck, P., Pradisthakarn, N., Authanithee, F. and Keebjan, P. (2008). Effect of exogenous methyl jasmonate on chilling injury and quality of pineapple (Ananas comosus L.) cv. Pattavia. Silpakorn University Science and Technology Jordan, 2, 33-42. http://dx.doi.org/10.14456/sustj.2008.9.

Pandey, R. R., Aurora, D. K. and Dubey, R. C. (1997). Effect of environmental conditions and inoculum density on infection of guava fruits by Colletotrichum gloesporioides. Mycopathology, 137, 165-172.
Pérez, A. G., Sanz, C., Olías, R. and Olías, J. M. (1997). Effect of methyl jasmonate on in vitro strawberry ripening. Journal of Agricultural and Food Chemistry, 45, 3733-3737. http://dx.doi. org/10.1021/jf9703563.

Pérez, A. G., Sanz, C., Richardson, D. and Olias, J. M. (1993). Methyl jasmonate vapor promotes -carotene synthesis and chlorophyll degradation in Golden Delicious apple peel. Journal of Plant Growth Regulation, 12, 163-167. http://dx.doi. org/10.1007/BF00189648.

Saniewski, M. (1997). The role of jasmonates in ethylene biosynthesis. In A. K. Kanellis, North Atlantic Treaty Organization, Scientific Affairs Division, Biology and biotechnology of the plant hormone ethylene (p. 39-45). Dordrecht: Kluwer Academic Publishers.

Saniewski, M., Czapski, J., Nowacki, J. and Lange, E. (1987). The effect of methyl jasmonate on ethylene and 1-aminocyclopropane-1-carboxylic acid production in apple fruits. Biologia Plantarum, 29, 199-203. http://dx.doi.org/10.1007/ BF02876829.

Soto, A., Ruiz, K. B., Ziosi, V., Costa, G. and Torrigiani, P. (2012). Ethylene and auxin biosynthesis and signaling are impaired by methyl jasmonate leading to a transient slowing down of ripening in peach fruit. Journal of Plant Physiology, 169, 18581865. http://dx.doi.org/10.1016/j.jplph.2012.07.007.

Terry, L. A. and Joyce, D. C. (2004). Elicitors of induced disease resistance in postharvest horticultural crops: a brief review. Postharvest Biology and Technology, 32, 1-13. http://dx.doi. org/10.1016/j.postharvbio.2003.09.016.

Tzortzakis, N. G. (2007). Methyl jasmonate-induced suppression of anthracnose rot in tomato fruit. Crop Protection, 26, 15071513. http://dx.doi.org/10.1016/j.cropro.2006.12.014.

Venkatachalam, K. and Meenune, M. (2015). Effect of methyl jasmonate on physiological and biochemical quality changes of longkong fruit under low temperature storage. Fruits, 70, 69-75. http://dx.doi.org/10.1051/fruits/2014046.

Wang, S. Y. and Zheng, W. (2005). Preharvest application of methyl jasmonate increases fruit quality and antioxidant capacity in raspberries. International Journal of Food Science Technology, 40,187-195. http://dx.doi.org/10.1111/j.1365-2621.2004.00930.x.

Wills, R., McGlasson, B., Graham, D. and Joyce, D. (1999). Introducción a la fisiologia y manipulación poscosecha de frutas, hortalizas y plantas ornamentales. Zaragoza: Acribia. 
Yao, H. J. and Tian, S. P. (2005a). Effect of pre- and post-harvest application of salicylic acid or methyl jasmonate on inducing disease resistance of cherry fruitin storage. PostharvestBiology and Technology, 35, 253-262. http://dx.doi.org/10.1016/j.postharvbio.2004.09.001.

Yao, H. J. and Tian, S. P. (2005b). Effects of a biocontrol agent and methyl jasmonate on postharvest diseases of peach fruit and the possible mechanism involved. Journal of Applied Microbiology, 98, 941-950. http://dx.doi.org/10.1111/j.1365-2672.2004.02531.x.

Yu, M., Shen, L., Fan, B., Zhao, D., Zheng, Y. and Sheng, J. (2009). The effect of MeJA on ethylene biosynthesis and induced disease resistance to Botrytis cinerea in tomato. Postharvest Biology and Technology, 54, 153-158. http://dx.doi. org/10.1016/j.postharvbio.2009.07.001.

Zapata, P. J., Martinez-Espla, A., Guillen, F., Diaz-Mula, H. M., Martinez-Romero, D., Serrano, M. and Valero, D. (2014).
Preharvest application of methyl jasmonate (MeJA) in two plum cultivars. 2. Improvement of fruit quality and antioxidant systems during postharvest storage. Postharvest Biology and Technology, 98, 115-122. http://dx.doi.org/10.1016/j. postharvbio.2014.07.012.

Zhang, F. S., Wang, X. Q., Ma, S. J., Cao, S. F., Li, N., Wang, X. X. and Zheng, Y. H. (2006). Effects of methyl jasmonate on postharvest decay in strawberry fruit and the possible mechanisms involved. Acta Horticulturae, 712, 693-698. http:// dx.doi.org/10.17660/ActaHortic.2006.712.87.

Ziosi, V., Bonghi, C., Bregoli, A. M., Trainotte, L., Biondi, S., Sutthiwal, S., Kondo, S., Costa, G. and Torrigiani, P. (2008). Jasmonate-induced transcriptional changes suggest a negative interference with the ripening syndrome in peach fruit. Journal of Experimental Botany, 59, 563-573. http://dx.doi.org/10.1093/ jxb/erm331. 